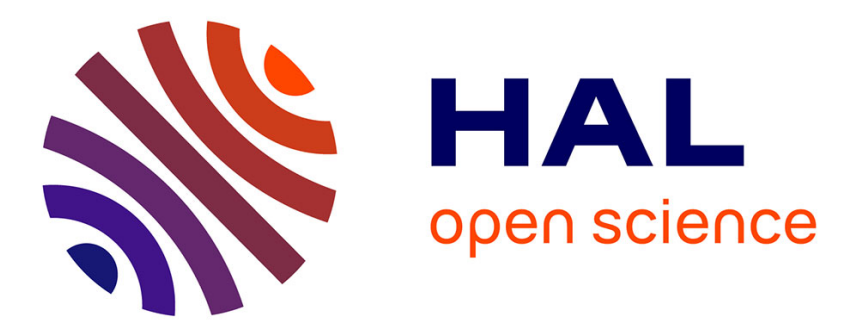

\title{
Using your Ties to Get a Worse Job? The Differential Effects of Social Networks on Quality of Employment in Colombia
}

Thibaud Deguilhem, Jean-Philippe Berrou, François Combarnous

\section{- To cite this version:}

Thibaud Deguilhem, Jean-Philippe Berrou, François Combarnous. Using your Ties to Get a Worse Job? The Differential Effects of Social Networks on Quality of Employment in Colombia. Review of Social Economy, 2019, 77 (4), pp.439-522. 10.1080/00346764.2019.1627573 . halshs-02276337

\section{HAL Id: halshs-02276337 \\ https://shs.hal.science/halshs-02276337}

Submitted on 2 Sep 2019

HAL is a multi-disciplinary open access archive for the deposit and dissemination of scientific research documents, whether they are published or not. The documents may come from teaching and research institutions in France or abroad, or from public or private research centers.
L'archive ouverte pluridisciplinaire HAL, est destinée au dépôt et à la diffusion de documents scientifiques de niveau recherche, publiés ou non, émanant des établissements d'enseignement et de recherche français ou étrangers, des laboratoires publics ou privés. 


\section{MPRA \\ Munich Personal RePEc Archive}

\section{Using your ties to get a worse job? The differential effects of social networks on quality of employment in Colombia}

Thibaud Deguilhem and Jean-Philippe Berrou and François Combarnous

University of Bordeaux, Sciences Po Bordeaux, University of Bordeaux

April 2017

Online at https://mpra.ub.uni-muenchen.de/85714/ MPRA Paper No. 85714, posted 5 April 2018 15:22 UTC 


\title{
Using your ties to get a worse job?* The differential effects of social networks on quality of employment in Colombia
}

\author{
Thibaud Deguilhem ${ }^{\dagger} \quad$ Jean-Philippe Berrou ${ }^{\ddagger} \quad$ François Combarnous $^{\S}$
}

\begin{abstract}
This article examines the effect of social networks by investigating how mobilizing family, friendship or kindship ties in job searches affects the quality of employment (QoE) using a mixed approach. Drawing from socioeconomic literature on the segmented labor market, the authors propose an original and multidimensional measure of job quality and a fruitful estimation of the effect of social networks on QoE that allows for dealing with complex inter-groups heterogeneity. Using the Great Integrated Household Survey (GIHS) and a sample on Bogota's workers in 2013, they provide empirical support that the use of ties is negatively correlated with the QoE for those who are vulnerable. Likewise, the use of social relations is not significant for protected workers. Complemented by focus groups interviews, these results raise questions about the difference prevailing in relational practices between necessity networks for precarious workers and opportunity networks for protected workers in the Colombian capital.
\end{abstract}

JEL. C14, J42, L14, O54, Z13

Keywords. Social networks, Quality of employment, Finite Mixture Regression Model, Mixed method, Colombia

\footnotetext{
*We would like to thank Ximena Peña and Isabelle Chort for sharing time, and for their most valuable suggestions and discussions. We also want to thank Eric Quintane, Santiago Goméz and Javier Mejia for the organization of the focus groups and useful comments. We also like to thank the participants to the Development Economics seminar of University of Bordeaux. We are grateful to the participants to various conferences, including those of the Society for the Advancement of Socio-Economics (2016) and the Latin American Studies Association (2017). We also want to thank the financial support of the C16H01 ECOS-Colciencias project (GREThA UMR-CNRS 5113 and CEDE scientific cooperation program).

$\dagger^{\dagger}$ Corresponding author: GREThA UMR-CNRS 5113, University of Bordeaux. Avenue Léon Duguit 33600 PESSAC (France). Tel.: +33 630609503. thibaud.deguilhem@u-bordeaux.fr

${ }^{\ddagger}$ LAM UMR-CNRS 5115, Sciences Po Bordeaux. j.p.berrou@sciencespobordeaux.fr

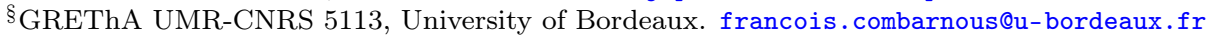




\section{Introduction}

Jobs and quality of employment are important challenges facing developing countries for their structural transformation (World Bank 2013; McMillan et al. 2014; OECD 2016). Since the 1980s, the context of increasing globalization, urbanization and political mutations has made it difficult to characterize urban labor market dynamics. However, a proper grasp of this social sphere is crucial in order to efficiently orient public policies on employment.

In a socioeconomic perspective, to understand the dynamics of labor markets it is essential to analyze the social and institutional processes in which individuals and markets are embedded (Callon 1998; Smelser and Swedberg 2005). Since Granovetter's seminal study ([1974] 1995), sociological and economic literatures have emphasized the importance of social networks in market functioning and in individual behaviors (Rauch and Cassella 2001; Smith-Doerr and Powell 2005; Jackson 2014). This relational embeddedness of economic actions means that abstracting from social interactions comes with the risk of severely misunderstanding behaviors and their causes (Granovetter 1985, 2017). In fact, designing many economic policies requires a deep understanding of social relations and network effects (Beaman 2016; Jackson et al. 2017). In developed labor markets, research on informal contacts shows that a major part of jobs and activities are obtained or developed through family, friends or relatives (Marsden and Gorman 2001; Topa 2011). A fortiori, this issue is crucial in developing countries which are characterized by the failure of formal institutions to channel information about market opportunities and in which social networks are employed very frequently in job search activity (Yakubovitch 2005; Fafchamps 2006; Nordman and Pasquier-Doumer 2015). In different institutional contexts, relational embeddedness plays an important but also ambiguous role in determining various labor market outcomes (Datcher Loury 2006; Pellizarri 2010; Matsuda and Nomura 2017). In fact, there are as many studies showing that social networks are positively correlated with better earnings and labor status (Kugler 2003; Magruder 2010; Yogo 2011) as there are demonstrating the opposite (Elliott and Sims 2001; Chua 2011; Diaz 2012).

In this article, we revisit these ambiguous results through an original framework observing the use of social networks in a segmented labor market. According to Bentolila et al. (2010), two main types of networks should generate contrasting results on the labor market, and these differential effects are influenced

by the heterogeneity and the multi-segmentation of labor markets, particularly in developing countries (Fields 2011). However, the heterogeneity of labor market outcomes is complex and inevitably comes under a multidimensional process, mixing social institutions and legal regulations (Kalleberg et al. 2000; 
Hudson 2007). In this way, using the quality of employment concept ${ }^{1}$ seems crucial (Osterman 2013; Burchell et al. 2014). This multidimensional approach holds a considerable interest, allowing for the precise analysis of employment forms and their further evolution while abandoning the classical typologies of the labor markets in a developing context (Floro and Messier 2011; Farné and Vergara 2015; Combarnous and Deguilhem 2016). In developed countries, few studies have emphasized the relation between social networks and quality of employment (Granovetter [1974] 1995:13-14). Yet they offer two unidimensional measures of job quality, holding income and job satisfaction as two fruitless approximations (Burchell et al. 2014). In developing countries, Nordman and Pasquier-Doumer (2015) have documented this issue with an approximation of quality of employment levels through a dichotomy between self-employment and wage employment (Bocquier et al. 2010). However, Combarnous and Deguilhem (2016) have shown that this typology is not relevant for dealing with the complexity of urban labor market in Colombia. Indeed, there is no longer a clear divide between job quality for employees and independents, which is in accordance with the idea of a continuum across employment statuses (Tokman 2007). In the specific Latin-American context, this paper seeks to analyze the determinants of quality of employment for workers in urban labor markets by highlighting the role played by the use of social networks.

Tackling these crucial questions for employment policies in Colombia, we outline an original empirical strategy to introduce a three-fold contribution to the line of research that investigates social networks in Latin American labor markets. First, we use a mixed approach combining a representative sample of workers in Bogota's labor market with focus group interviews to best capture the diversity of relational practices between workers' groups. Second, an original methodology is formulated to construct an index on thirteen variables corresponding to the six interconnected dimensions of the job quality concept and capturing Bogota's labor market institutions. Third, dealing with complex inter-groups heterogeneity, we offer an accurate estimation of the differential effects of the use of social networks on vulnerable versus protected workers.

This paper is organized as follows. Section 2 presents the institutional context of the Bogota's urban labor market, the data and the focus groups scheme. Section 3 introduces the theoretical framework, the method adopted to construct a relevant QoE index and the semi-parametric estimation strategy. Section 4 presents the econometric results and qualitatively explores qualitatively the raison d'être of the differential effects of networks for different workers groups. Finally, the last section discusses the findings and the methodological approach.

\footnotetext{
${ }^{1}$ See Burchell et al. (2014) for a specific overview on the quality of employment concept.
} 


\section{Context and Data}

\subsection{Bogota's urban and labor market contexts}

In 2013, the city of Bogota had nearly 7.6 million inhabitants, compared to 715,000 in 1951 . It now represents nearly $17 \%$ of the Colombian population, an $87 \%$ increase from 1985 . Despite a low birth rate, and a downward trend in the average annual urbanization rate - going from $7 \%$ between 1950 and 1955 to $1.36 \%$ between 2010 and 2015 - the capital district remains marked by the urban change arising from internal migration. It forms a "hub of the territorial system," hosting populations from the forced displacements caused by internal conflict (Dureau et al. 2015:35). Faced with expanding informal urbanization and growing inequalities, the government implemented a socioeconomic space stratification method to introduce a mixed subsidy mechanism for municipal services payments. Various homogeneous groups of buildings (6 groups) were established on the basis of the land registry zones. These "blocks" of homogeneous residences provide a satisfactory approximation of the social hierarchy: the poorest $(1,2$ and 3 ), representing almost $90 \%$ of the population in 2013, receive support for between $40 \%$ and $10 \%$ of the cost of services, whereas the richest ( 5 and 6 ) pay a surcharge of between $40 \%$ and $20 \%$. Since the introduction of this policy, Bogota has followed an insular, residentially-segregated developmental logic, between a northeastern zone occupied by the wealthiest households, a southern area inhabited by poor households, and a western area occupied by the middle class (Dureau et al. 2015:113-114). This social hierarchization directly determines household location decisions and influences social group identity in terms of access to education, healthcare and employment (SDP 2013). Unlike other Andean metropolis, Bogota has a relatively low rate of poverty at $17 \%$ in 2011 . It remains high, however in the south of the city and in stratum 1 and 2: $40 \%$ for stratum 1 and $25 \%$ for stratum 2 (SDP 2013). Illustrating this heterogeneous situation, the capital city has observed a significant increase in income inequality, with the Gini index for income increasing from 0.51 in 2008 to 0.61 in $2013 .^{2}$ Moreover, in 2013 the Bogota's labor market concerns more than 4 millions people, with an occupation rate of $65,5 \%$ and $9 \%$ of unemployment. Like other Latin American countries, 34\% of active workers appear in subjective underemployment, $21.7 \%$ in skill-related inadequate employment and $28.2 \%$ in income-related inadequate employment (DANE 2014). ${ }^{3}$ To challenge these facts and implement appropriate employment policies, the Servicio Publico del Empleo (SPE) was established in the last trimester of 2013 in Colombia (Law 1636 of 2013), but more than 65\% of workers found their current job through their social relations in the same year. ${ }^{4}$

\footnotetext{
${ }^{2}$ The 2008 Gini index came from Bogota's Department of District Planning (SDP 2013). Authors have calculated the 2013 Gini index on the basis of the 2013 household survey.

${ }^{3}$ In 2013, the monthly minimum wage was 589500 pesos (Article 145 of the Codigo Sustantivo de Trabajo).

${ }^{4}$ Authors calculations.
} 


\subsection{Quantitative and qualitative data}

The data comes from the 2013 Great Integrated Household Survey (GIHS) produced by the National Administrative Department of Statistics. Our analysis covers a representative sample of 5,846 workers (18-95 years old) who are employed in Bogota's labor market. As such, workers between 15 and 17 years old are excluded because they do not have "normal" rights in their working conditions. Moreover, we excluded workers working more than 120 hours per week. ${ }^{5}$ Socioeconomic covariates were drawn from the individual, household and employment characteristics that are relevant for the Bogota's labor market analysis (Appendix B).

Moreover, we complement the quantitative approach with focus groups interviews. Following Crossley et al. (2015:62), "qualitative methods are useful for investigating unexplored networks; concrete acts, practices and interactions; actors' perceptions and assessment of relationships [...]." In other words, with qualitative methods we explore the content and meaning of relationships, as well as the import of the overall structure of individual social environments. We coordinated six focus group sessions ${ }^{6}$ to collect qualitative accounts on the different experiences of getting a job via social networks in Bogota. The objective was to understand how individuals choose where to look or who to ask in their job search effort. The main criterion for structuring the composition of the groups was finding a balance between the diversity of information extractable from a heterogeneous group, and the incentives to express ideas resulting from being part of a homogeneous group (Madriz 1998). ${ }^{7}$ We selected two types of groups ${ }^{8}$ the dimension used for considering the homogeneity of each group was the segment of the labor market in which the members participate. The reason for this is that the labor market segmentation is fairly strong between low and high quality jobs (Farné and Vergara 2015; Combarnous and Deguilhem 2016). In addition, this dimension is linked with income and socioeconomic strata, which summarizes most of the institutional differences in Colombia.

\footnotetext{
${ }^{5} 120$ hours per week is equivalent to more than 17 hours on the workplace, and some studies, using the Time Use Surveys, have documented that the biological time for the reproduction can not be less than 7 hours per day (Hamermesh and Stancanelli 2015).

${ }^{6} 3$ sessions of 2 groups (separating vulnerable and protected workers) of 5 individuals on average. Each discussion per group lasted an average of 90 minutes. During each discussion, the facilitator coordinated the discussion and the participants provided a narrative of how they got a job. The relator recorded the conversation, took observational notes on the the participants, marked the time as well as key moments in the discussion.

${ }^{7}$ People are more comfortable talking when they are with their peers.

${ }^{8}$ The group members have were selected in the most frequented stations of the Transmilenio (Bus Rapid Transit System of Bogota) in the city center.
} 


\section{Theoretical framework and empirical strategy}

\subsection{The differential effects of social networks on a segmented labor market}

Some theoretical and empirical studies argue that social networks generate opportunities and are a good channel for the transmission of job information for job-seekers or employees. For unemployed workers, the use of ties may reduce the time it takes to exit rates unemployment (Bramoullé and Saint-Paul 2010). Kramarz and Skans (2014) indicate that parental ties are an important determinant of how Swedish young workers find and progress in their job. In the United-States, Hispanic men report more frequent use of friends and relatives for job searches than non-Hispanic, and a majority had found their most recent job through personal networks (Smith 2000). In developing countries, Magruder (2010) demonstrates that using the father's networks has a positive effect on the son's employment in the South African context. In India, Beaman and Magruder (2012) provide evidence that some workers, those with high skill levels, have useful information about the abilities of members of their social network members, reducing the asymmetrical information problem and making it faster to find a job. In the same way, Nordman and Pasquier-Doumer (2015) indicate that social networks seem to influence the probability of getting a job when individuals are unemployed in Burkina Faso. Regarding the positive effect of social networks on earnings, Calvó-Armengol and Jackson (2004) demonstrate theoretically that the higher the wages of contacts, the more information they are willing to give to others. They also show that individuals are more likely to earn higher wages if their contacts are part of more extensive networks and are employed (CalvóArmengol and Jackson 2007). Some empirical studies corroborate these results in different institutional context, showing that those who found their job through family, friends and relatives earned more than those using formal methods (Kugler 2003; Antoninis 2006). Other authors have documented the positive correlation between the use of ties and the poverty reduction in China (Zhang et al. 2017).

However, social networks also produce negative effects for specific types of workers on the labor market. If social ties are a good channel for receiving new informations on the market opportunities, Brady (2015) explicates that this effect varies by location, sociodemographic characteristic and type of relation. Some studies argue that those using contacts earned less than those employing formal means or had no persistent wage effects (Bentolila et al. 2010). In developing countries, Antoninis (2006) has also argued that the use of referrals from friends and relatives has no effect on an individual's starting wage and may even be negatively related to the wages of unskilled laborers in the Egyptian context. Marques (2012) has shown that relational settings strongly influence individuals access to markets, leading some Brazilian people into worse living conditions and poverty. In Malawi, Beaman et al. (2018) has also demonstrated 
that men systematically refer few women, despite being able to refer qualified Indian women when explicitly asked about female candidates. Moreover, social capital and kinship ties sometimes appear risky; therefore, they may not be a useful predictor of success -for small-scale fisheries (Crona et al. 2016)and could produce an over-embeddedness or redistributive pressure (forced solidarity) for small business workers or community members (Berrou and Combarnous 2011, 2012; Nguyen and Nordman 2018; Di Falco et al. 2018).

Confronted with this contrasting literature reviews, we built an original theoretical framework to explain why these heterogeneous results have been observed. We started from the idea of heterogeneity between different social groups in terms of ex post job quality, and we assumed that a clear distinction exists between high and low job quality groups in the labor market (Farné and Vergara 2015; Combarnous and Deguilhem 2016). To obtain a job, a worker may have used different means with distinct effects depending on his group (Bentolila et al., 2010). In particular, the use of social networks ex ante can have two effects for the two heterogeneous groups (Figure 1). In other words, job quality depends on the type of workers (protected or vulnerable) in the activated network and the differential effects can be especially related to the form of the links that have actually been activated to get the job in question. Following this idea illustrated in Figure 1, we can distinguish two basic functions and outline four hypotheses:

- Securing and supporting actors with different types of risk in the labor market. In other words, networks are seen as a last resort and a social constraint, characterizing a necessary safety net for the vulnerable (Smith 2000, 2016; Marques 2012).

- Establishing a privileged channel for spreading information about the job opportunities offered or created. The networks are then considered a means of circulating information within and between social groups, especially in wealthier groups (Tholen et al. 2013; Sharone 2014).

H1a: For protected workers, networks serve for disseminating information about new and better opportunities.

Protected workers have privileged access to information on new opportunities through the use of "good" relationships with employees or independents who can contribute to the success of the business. Thus, the networks of these workers can be considered as a social means to facilitate the flow of specific informations concerning jobs or ideas (Granovetter 1973, [1974] 1995; Beaman and Magruder 2012), and help employers to select workers (Ekinci 2016; Hensvik and Skans 2016). In the end, the relationships of workers in this group can be understood as opportunity networks insofar as their use should lead to a better job. Com- 
Figure 1: Opportunity and necessity networks effects in segmented labor market

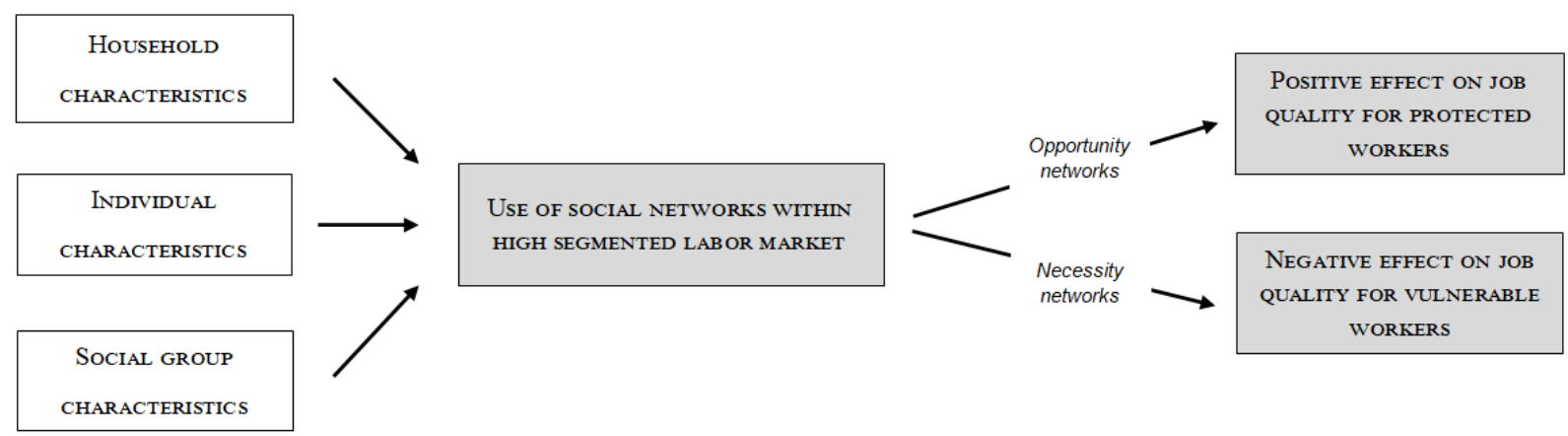

Source: Authors.

pared to "formal" means, it seems fairly intuitive to think that the use of these networks should not differ from the use of other schemes in terms of job quality.

H1b: Opportunity networks are supported by weak ties.

The opportunity networks available to protected workers could be envisaged through the specific characteristics of the links connecting individuals and their activated contacts (Granovetter 1982). Following Granovetter's (1973, [1974] 1995) assumption that interpersonal relations may be perceived as the combination of a quantity of time, emotional intensity, intimacy, and reciprocal services, we can distinguish strong and weak ties. Developing his argument and agreeing with Burt's (1995) approach, Granovetter points out that weak ties represent necessary bridges between social groups that would be served without the existence of these connections and contacts. Thus, this type of ties generates a better circulation and distribution between groups, while also producing strategic advantages and benefits for intermediate actors (brokers), who then have new and non-redundant information coming from different groups (Burt 1995; Davern and Hachen 2006). That opportunity networks and "formal" means for protected workers have similar effects may be due to the availability and the use of weak ties (Granovetter 1982; Yakubovith 2005).

H2a: For vulnerable workers, social networks constitute a "poor quality job trap".

Conversely in the vulnerable group, workers do not possess information on more favorable employment quality opportunities (Bentolila et al., 2010), but still use their links to obtain a job despite the weakness of the proffered positions. Compared to "formal" means, the use of social networks appears negatively correlated with the job quality, isolating individuals from the best opportunities and increasing their vulnerability (Fernandez and Fernandez-Mateo 2006; Marques 2012). This hypothesis seems quite consistent with many studies that highlight this aggravating factor for unskilled individuals or at the bottom of 
income distribution (Diaz 2012; Garcia and Nicodemo 2015).

H2b: Necessity networks are supported by strong ties.

In line with what we have mentioned about opportunity relations, this hypothesis can be extended by the works of Granovetter (1982) and Smith (2000) who argue that these networks of necessity may be essentially composed of strong ties. In contrast to what we said for the proctected group, we note a "poor quality trap" process for vulnerable workers, because they do not have weak connections and therefore use mostly strong relationships with similar workers, accessing redundant information about low employment quality job opportunities (Smith 2016).

\subsection{The quality of employment index}

Combarnous and Deguilhem (2016) demonstrate that the quality of employment concept must be situated in legal and social contexts. Despite this necessity, they show that the following six dimensions mark the "core" of QoE (Floro and Messier 2011; Osterman 2013; Burchell et al. 2014; Farné and Vergara 2015): (i) income level, (ii) working conditions and legal status, (iii) the possibilities of reconciling work and family life, (iv) social securities, (v) collective employment components, (vi) the subjective dimension given to the job. Specifically in Latin America, some studies establish various QoE indicators by raising the type of contract, social security coverage, income and working time, multiple activities, workplace, employment security and/or non-wage benefits.

Following Combarnous and Deguilhem (2016), we opted for a multivariate strategy to formulate the QoE index. In light of the categorical nature of household survey data, the Multiple Correspondence Analysis (MCA), with its quite robust $\chi^{2}$ metric, constitute an appropriate technique (Greenacre 1993). This approach is an empirical method adapted to construct a contextualized QoE index based on the factorial scores of each category of selected QoE indicators (OECD 2008).

Let us assume that the first factorial axis meets the consistency conditions to be considered as a quality of employment factor. As such, we can define as an appropriate composite indicator: $Q o E=F_{1}$. In this sense, the $Q O E$ index for every worker is calculated from the normalized score of each category of the variables coming back into the composition of the first factorial axis of the MCA. We can express the 
quality of employment index for the individual $i$ under the following functional form:

$$
Q o E_{i}=\frac{\sum_{q=1}^{q} \sum_{j_{q=1}}^{j_{q}} W_{q}^{1, q_{j}} K_{i, j_{q}}^{q}}{Q}
$$

Where $\mathrm{Q}$ corresponds to the number of categorical or ordinal variables of $\mathrm{QoE}, W_{j_{q}}^{1, q}=\frac{w_{j_{q}}^{1, q}}{\sqrt{\kappa_{1}}}$ is the normalized category-score $j_{q}$ of the variable $q$ on the first factorial axis $\kappa_{1} . K_{i, j_{q}}^{q}$ is a binary variable, taking a value of 1 when the individual $i$ presents the category $j_{q}, 0$ otherwise.

The value of the QoE index corresponds well to the normalized category-score average on the first factorial axis of the MCA. We have : $Q o E_{i} \in[-1 ; 1]$ that we brought back into $[0 ; 1]$ by linear interpolation to make the reading easier. Then, we have a continuous QoE index: $Q_{o} E_{i} \in[0 ; 1]$, with 0 corresponding to the worst possible job quality, and 1 corresponding to the best possible QoE in this social context.

According to legal and socioeconomic institutions in the Bogota's urban labor market (Farné and Vergara 2015; Combarnous and Deguilhem 2016), we have therefore selected 13 variables to build this QoE index (Appendix A).

\subsection{Finite Mixture Regression Model (FMRM)}

This approach simultaneously allows us to identify heterogeneous groups and to estimate each specific regression model an econometric strategy derived from McLachlan and Peel (2000), Deb et al. (2011) and Günther and Launov (2012)-. When applying a FMRM, the number of groups is not known and must therefore be inferred from the data. Choosing the number of components $C$ can then be carried out with different methods, depending on which has placed a greater interest in the quality of the adjustment of density or in the detection of distinct groups (McLachlan and Peel 2000). Thus, if the main interest concerns the estimation of density, the proper method is to select the value $C$ which minimizes the AIC and the BIC (Ben Salem and Bensidoun 2012).

In order to analyze the effect of social networks on the QoE index in a segmented context, the mixture of linear regressions serves to specify the conditional expectation of a dependent variable $(Q o E)$ as a linear function of the use of ties $(S N W)$ and other explanatory variables. In this way, we use three blocks of explanatory variables $(S):{ }^{9}$ individual (education, gender, marital status, age), household (socioeconomic strata) ${ }^{10}$ and employment characteristics (activity sector). One approach is to likewise specify the

\footnotetext{
${ }^{9}$ For more variable details, see Appendix B.

${ }^{10}$ Socioeconomic strata are a proxy for geographical opposition between South and North.
} 
average of the density functions for each of the mixture groups.

The average of the densities is obtained from the FMRM estimation, as conditional on the values of the variable of interest $S N W$ and other explanatory variables $S$. Looking at two components $(C=2)$, we consider the following Gaussian mixture model, where $\epsilon_{i}^{1}$ et $\epsilon_{i}^{2}$ are independent error terms, identically distributed following a normal distribution:

$$
\left.\begin{array}{l}
\mathrm{C} 1: Q o E_{i}^{1}=\beta_{0}^{1}+S N W_{i}^{1} \beta_{1}^{1}+S_{i}^{1} \beta_{2}^{1}+\epsilon_{i}^{1} \\
\mathrm{C} 2: Q o E_{i}^{2}=\beta_{0}^{2}+S N W_{i}^{2} \beta_{1}^{2}+S_{i}^{2} \beta_{2}^{2}+\epsilon_{i}^{2}
\end{array}\right\}
$$

This analysis would be fine if the use of social networks were completely independent from others observable characteristics. However, the decision whether to use social networks is not randomly distributed (Appendix B). It is likely that some of the individuals who may be in specific situations choose not to use contacts and this would be considered in the estimation process. In fact, some studies in Latin America demonstrate that being poor, having a low educational level and working in small firm size increase the probability of using ties (Portes 2010; Marques 2012). We resolve that issue by applying the Heckman twostep approach (1979): (i.) estimate a selection equation with a Probit model and determine the correction parameter $(\lambda)$ corresponding to Inverse Mills Ratio (IMR) for each individual, (ii.) include this correction as a predictor in the determination equations. Thus, the linear regression mixture model (FMRM) that we estimate in the next section can be formalized as follow (with always $C=2$ ):

$$
\left.\begin{array}{l}
\mathrm{C} 1: Q o E_{i}^{1}=\beta_{0}^{1}+S N W_{i}^{1} \beta_{1}^{1}+X_{i}^{1} \beta_{2}^{1}+Z_{i}^{1} \beta_{3}^{1}+E_{i}^{1} \beta_{4}^{1}+\lambda_{i}^{1} \beta_{5}^{1}+\epsilon_{i}^{1} \\
\mathrm{C} 2: Q o E_{i}^{2}=\beta_{0}^{2}+S N W_{i}^{2} \beta_{1}^{2}+X_{i}^{1} \beta_{2}^{2}+Z_{i}^{2} \beta_{3}^{2}+E_{i}^{2} \beta_{4}^{2}+\lambda_{i}^{2} \beta_{5}^{2}+\epsilon_{i}^{2}
\end{array}\right\}
$$

In the last determination equations (3), the model offers to regress the dependent variable $Q o E^{c}$ on the variable of interest $S N W^{c}$ for each component, controlled by a set of covariables: individual $X^{c}$, household $Z^{c}$, employment characteristics $E^{c}$ and an error term $\epsilon^{c}$. According to the Heckman two-step procedure, these specifications also include the coefficient $\lambda^{c}$. 


\section{Differential effects of using ties in Bogota's segmented labor market}

\subsection{Descriptive analysis}

The distribution of QoE index clearly shows two different modes (Figure 2), proving a polarization in the quality of employment in Bogota and forming two groups of QoE. On the left-hand side, the first mode represents a "poor" quality of employment for precarious and vulnerable workers whereas on the right-hand side, the second mode shows a "strong" quality group, benefiting from social and lawful protection. Confirming Combarnous and Deguilhem (2016), the summary statistics reported in Appendix B demonstrate that it is more relevant to treat the gap between "good" and "bad" jobs rather than to analyze status typology (Bocquier et al. 2010).

Figure 2: QoE index and QoE index by using ties to get a job, GIHS (2013)
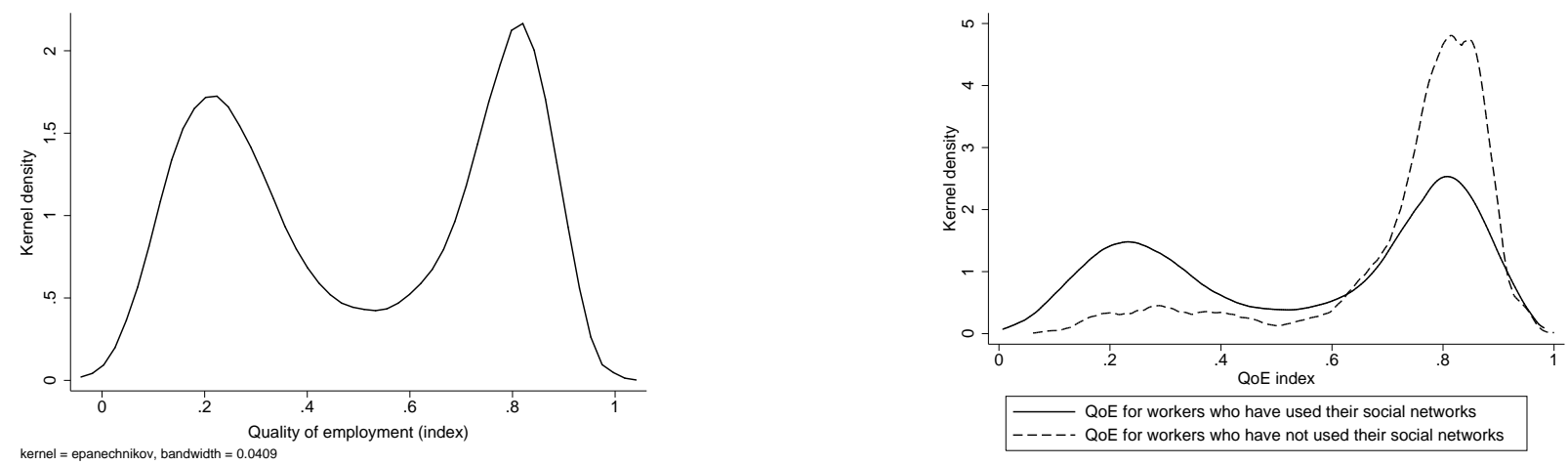

Source: Authors, Departamento Administrativo Nacional de Estadistica (DANE): www.dane.gov.co

Figure 3: QoE index for independents and employees, GIHS (2013)
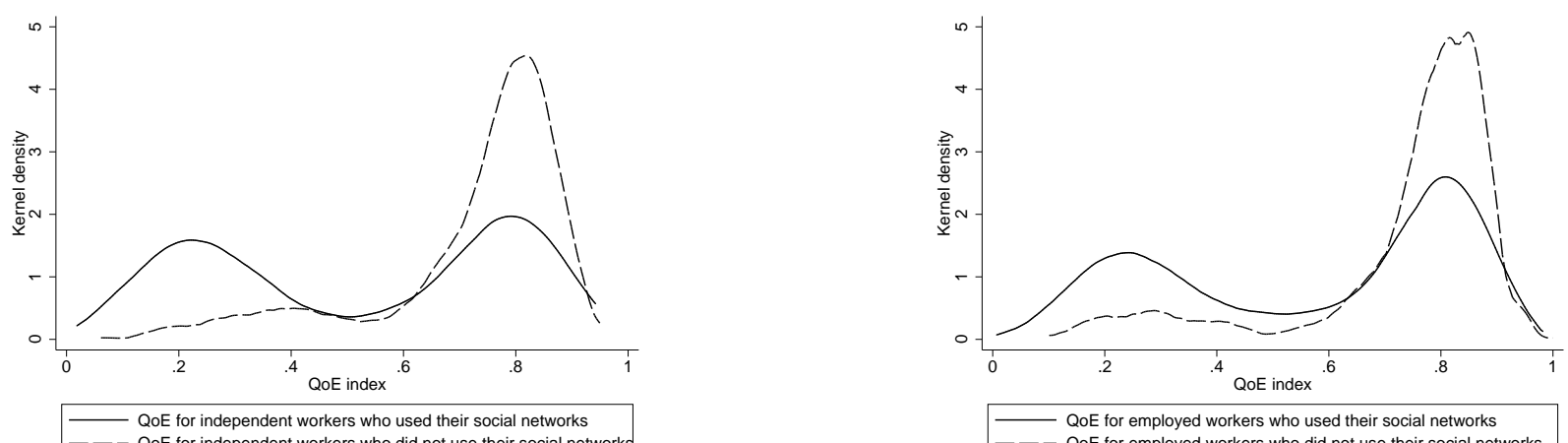

QoE for independent workers who used their social networks QoE for employed workers who usd their social networks

Source: Authors, Departamento Administrativo Nacional de Estadistica (DANE): www.dane.gov.co

Figures 2 and 3 show the bimodal distribution of the use of ties for all workers, employees and indepen- 
dents. Indeed, among those who mobilized ties, both populations -vulnerable and protected workers- use social relations to obtain a job. In other words, the different social "circles" constitute reference groups affecting relational practices, social behaviors and labor market outcomes (Granovetter [1974] 1995; Bott 2002; Grossetti 2005). This inter-group heterogeneity illustrated by Figures 2 and 3 justifies our use of FMRM in the estimation step. Moreover, we check the relevance of this empirical strategy with quantile regressions. Indeed, we consider different percentiles in the QoE index distribution so as to test the stability and robustness of the FMRM estimations. In this way, we switch between a semi-parametric to a non-parametric model with bootstrapped standard errors to compare with a robust standard deviation in the models of interest (Appendix D).

\subsection{Estimation results}

Confirming Figures 2 and 3, Table 1 shows that separating QoE into two segments is preferable to other options looking for information criteria values. The parameters can thereby be clearly identified and we avoid the over-parametrized problem (Ben Salem and Bensidoun, 2012).

Table 1: Model selection and number of components

\begin{tabular}{lcccccc}
\hline \hline & \multicolumn{2}{c}{ Total sample } & \multicolumn{2}{c}{ Employees } & \multicolumn{2}{c}{ Independents } \\
& AIC & BIC $^{a}$ & AIC & BIC $^{a}$ & AIC & BIC $^{a}$ \\
\hline 2 Components & $\mathbf{6 5 6 3 . 3 6}$ & $\mathbf{6 4 2 0 . 0 4}$ & $\mathbf{5 0 1 7 . 5 8}$ & $\mathbf{4 7 5 6 . 4 6}$ & $\mathbf{1 5 5 1 . 7 7}$ & $\mathbf{1 4 6 3 . 2 1}$ \\
3 Components & 6652.98 & 6436.24 & 5141.77 & 4943.93 & 1690.20 & 1556.27 \\
4 Components & 7130.78 & 6840.63 & 5251.16 & 4986.30 & 1803.93 & 1624.64 \\
\hline \hline
\end{tabular}

Note: ${ }^{a}$ Sample size adjusted BIC.

Source: Authors, Departamento Administrativo Nacional de Estadística (DANE): www. dane.gov.co

Tables 2, 3 and 4 present the estimation results (FMRM and OLS) of the QoE index for the total sample, with employees and independents represented separately. The significance of the IMR correction term $(\lambda)$ for all specifications actually suggests that certain variables influence an individual's decision to mobilize their networks and their quality of employment in the Bogota labor market. The estimation of a FMRM without correction term would have led to biased estimated coefficients. In fact, the use of social networks is well established as the main mode of employment distribution in the Colombian capital (Combarnous and Deguilhem 2016), despite its weakening among the most educated and large scale business workers. In other words, the Probit estimations (selection stage) verify that people who have predominantly used their relationships to obtain their current job are less educated and less likely to work in large firms (Portes 2010; Marques 2012) (Appendix C). These observations tend to confirm the perception of a potential selection 
bias, as described in the previous section.

Furthermore, the different OLS estimates reported in the Tables 2, 3 and 4 show that the use of social networks is on average significantly anti-correlated with the QoE of individuals $(-3.3 \%$ for the total sample, $-2.8 \%$ for the employees and $-4.5 \%$ for the independents). This result, which obviously does not distinguish between workers but gives an average coefficient, suggests a general negative relation between this mode of social intermediation to increase the job quality in Bogota. However, it is clear that these results contrast sharply with those of the estimates from the FMRM models.

In fact, observing FMRM estimations presented in the Tables 2, 3 and 4, we clearly notice the differential effects of using ties between vulnerable and protected workers. In the first component, vulnerable people are effectively penalized in their quality of employment when they use their networks. Conversely, participants (protected) in the second do not show any significant decrease or increase in their quality of employment following the mobilization of their networks compared to other formal channels.

More specifically, we find that the use of contacts is significantly anti-correlated (respectively $-3.6 \%$ for all workers, $-3.3 \%$ for employees and $-4.5 \%$ for independents) with job quality within the lower group (Tables 2, 3 and 4). This result confirms the H2a hypothesis and also appears quite consistent with other studies conducted in Latin America, reporting this relational intermediation as a penalizing factor for unskilled individuals or for those at the bottom of income distribution (Diaz 2012; Marques 2012; Garcia and Nicodemo 2015). In order to test the robustness of this relationship and whether it would not be the result of a statistical artifact related to the determination of the two groups, we keep the same specification in the quantile regressions. Confirming the FMRM results, this negative and significant correlation arises in the first percentiles of the distribution of the job quality index $(q 10, q 20$ and $q 30$, Appendix D). In other words, for vulnerable individuals, the use of networks significantly affects their job quality, making them less protected than they already were.

For the protected workers, we observe that the use of contacts compared to more formal means is not significantly correlated with the quality of their employment (Tables 2, 3 and 4). This result tends to confirm the hypothesis $H 1 a$ and seems to be robust compared to quantile estimates on the total sample and for employees, except for independents (Appendix D). Indeed, quantile regressions reported in the same Appendix D verify the FMRM estimations and suggest a relevant break in the negative and significant 
Table 2: FMRM and OLS for QoE index (total sample), GIHS (2013)

\begin{tabular}{|c|c|c|c|}
\hline \multirow[b]{2}{*}{ Variable } & \multicolumn{2}{|c|}{ FMRM } & \multirow[t]{2}{*}{$\overline{\mathrm{OLS}}$} \\
\hline & Component 1 & Component 2 & \\
\hline Social Networks & $\begin{array}{c}-\mathbf{0 . 0 3 6}^{* * *} \\
(0.009)\end{array}$ & $\begin{array}{l}\mathbf{- 0 . 0 0 1} \\
(0.002)\end{array}$ & $\begin{array}{c}-\mathbf{0 . 0 3 3}^{\text {*** }} \\
(0.005)\end{array}$ \\
\hline Age & $\begin{array}{c}0.001 \\
(0.001)\end{array}$ & $\begin{array}{c}0.000 \\
(0.000)\end{array}$ & $\begin{array}{c}0.000 \\
(0.001)\end{array}$ \\
\hline $\mathrm{Age}^{2}$ & $\begin{array}{l}-0.000 \\
(0.000)\end{array}$ & $\begin{array}{c}0.000 \\
(0.000)\end{array}$ & $\begin{array}{c}0.000 \\
(0.000)\end{array}$ \\
\hline Education & $\begin{array}{c}0.002^{* * *} \\
(0.001)\end{array}$ & $\begin{array}{c}0.002^{* * *} \\
(0.000)\end{array}$ & $\begin{array}{c}0.002^{* * *} \\
(0.001)\end{array}$ \\
\hline Gender (women) & $\begin{array}{l}-0.013^{*} \\
(0.007)\end{array}$ & $\begin{array}{l}-0.002 \\
(0.003)\end{array}$ & $\begin{array}{c}-0.011^{* *} \\
(0.005)\end{array}$ \\
\hline Strata 2 & $\begin{array}{c}0.011 \\
(0.009)\end{array}$ & $\begin{array}{c}0.019^{* * *} \\
(0.005)\end{array}$ & $\begin{array}{c}0.028^{* * *} \\
(0.008)\end{array}$ \\
\hline Strata 3 & $\begin{array}{c}0.030 * * * \\
(0.010)\end{array}$ & $\begin{array}{c}0.023^{* * *} \\
(0.005)\end{array}$ & $\begin{array}{c}0.037^{* * *} \\
(0.009)\end{array}$ \\
\hline Strata 4,5 et 6 & $\begin{array}{c}0.087^{* * *} \\
(0.016)\end{array}$ & $\begin{array}{c}0.023^{* * *} \\
(0.006)\end{array}$ & $\begin{array}{c}0.068^{* * *} \\
(0.012)\end{array}$ \\
\hline Married & $\begin{array}{c}0.016^{* *} \\
(0.008)\end{array}$ & $\begin{array}{c}0.005 \\
(0.003)\end{array}$ & $\begin{array}{c}0.012^{* *} \\
(0.006)\end{array}$ \\
\hline$\lambda$ & $\begin{array}{c}0.581^{* * *} \\
(0.017)\end{array}$ & $\begin{array}{c}0.061^{* * *} \\
(0.007)\end{array}$ & $\begin{array}{c}0.504^{* * *} \\
(0.011)\end{array}$ \\
\hline$\sigma_{c}$ & $\begin{array}{c}0.148 \\
(0.002)\end{array}$ & $\begin{array}{c}0.051 \\
(0.001)\end{array}$ & \\
\hline$\pi_{c}{ }^{a}$ & $\begin{array}{c}0.547 \\
(0.010)\end{array}$ & $\begin{array}{c}0.452 \\
(0.010)\end{array}$ & \\
\hline Constant & $\begin{array}{c}0.145^{* * *} \\
(0.030)\end{array}$ & $\begin{array}{c}0.724^{* * *} \\
(0.013)\end{array}$ & $\begin{array}{c}0.291^{* * *} \\
(0.025)\end{array}$ \\
\hline $\begin{array}{c}\text { Log-likelihood } \\
\text { Wald } \chi^{2}\end{array}$ & $\begin{array}{r}332 \\
7032\end{array}$ & $\begin{array}{l}68 \\
3 * * *\end{array}$ & \\
\hline Adjusted $R^{2}$ & & & 0.497 \\
\hline VIF (average) & & & 4.88 \\
\hline $\mathrm{N}$ & & & 5846 \\
\hline
\end{tabular}

Note: Robust standard errors are in parentheses (Eicker-White correction) and the FMRM model converges in 14 iterations. Regressions also include activity sector dummies. The first component is the low quality of employment range and inversely for the second component.

${ }^{a} \pi_{c}$ is the probability that an observation is in component $c$. ${ }^{*} p<0.1,{ }^{* *} p<0.05,{ }^{* * *} p<0.01$.

Source: Authors, Departamento Administrativo Nacional de Estadistica (DANE): www.dane.gov.co

correlation between the use of networks and the quality of employment from the seventh decile for employees and the eighth decile for the total sample $(q 70, q 80$ and $q 90)$. In other words, for the $20 \%$ of the most protected workers in the sample (30\% for employees), the correlation between their use of relationships and their quality of employment appears visibly insignificant. 
Table 3: FMRM and OLS for QoE index (employees), GIHS (2013)

\begin{tabular}{|c|c|c|c|}
\hline \multirow[b]{2}{*}{ Variable } & \multicolumn{2}{|c|}{ FMRM } & \multirow[t]{2}{*}{$\overline{\mathrm{OLS}}$} \\
\hline & Component 1 & Component 2 & \\
\hline Social Networks & $\begin{array}{c}-\mathbf{0 . 0 3 3}^{* * *} \\
(0.010)\end{array}$ & $\begin{array}{c}\mathbf{0 . 0 0 0} \\
(0.003)\end{array}$ & $\begin{array}{c}-\mathbf{- 0 . 0 2 8}^{* * *} \\
(0.006)\end{array}$ \\
\hline Age & $\begin{array}{c}0.002 \\
(0.001)\end{array}$ & $\begin{array}{c}0.000 \\
(0.001)\end{array}$ & $\begin{array}{c}0.001 \\
(0.001)\end{array}$ \\
\hline $\mathrm{Age}^{2}$ & $\begin{array}{l}-0.000 \\
(0.000)\end{array}$ & $\begin{array}{c}0.000 \\
(0.000)\end{array}$ & $\begin{array}{l}-0.000 \\
(0.000)\end{array}$ \\
\hline Education & $\begin{array}{c}0.001 \\
(0.001)\end{array}$ & $\begin{array}{c}0.002^{* * *} \\
(0.000)\end{array}$ & $\begin{array}{c}0.002^{* * *} \\
(0.001)\end{array}$ \\
\hline Gender (women) & $\begin{array}{l}-0.010 \\
(0.008)\end{array}$ & $\begin{array}{l}-0.002 \\
(0.003)\end{array}$ & $\begin{array}{l}-0.012^{*} \\
(0.006)\end{array}$ \\
\hline Strata 2 & $\begin{array}{c}0.002 \\
(0.010)\end{array}$ & $\begin{array}{c}0.016^{* * *} \\
(0.006)\end{array}$ & $\begin{array}{c}0.028^{* * *} \\
(0.010)\end{array}$ \\
\hline Strata 3 & $\begin{array}{l}0.023^{*} \\
(0.012)\end{array}$ & $\begin{array}{c}0.020^{* * *} \\
(0.006)\end{array}$ & $\begin{array}{c}0.036^{* * *} \\
(0.010)\end{array}$ \\
\hline Strata 4,5 et 6 & $\begin{array}{c}0.062^{* * *} \\
(0.017)\end{array}$ & $\begin{array}{c}0.018^{* *} \\
(0.007)\end{array}$ & $\begin{array}{c}0.043^{* * *} \\
(0.013)\end{array}$ \\
\hline Married & $\begin{array}{c}0.012 \\
(0.010)\end{array}$ & $\begin{array}{c}0.004 \\
(0.004)\end{array}$ & $\begin{array}{c}0.010 \\
(0.007)\end{array}$ \\
\hline$\lambda$ & $\begin{array}{c}0.581^{* * *} \\
(0.022)\end{array}$ & $\begin{array}{c}0.054^{* * *} \\
(0.007)\end{array}$ & $\begin{array}{c}0.472^{* * *} \\
(0.013)\end{array}$ \\
\hline$\sigma_{c}$ & $\begin{array}{c}0.148 \\
(0.003)\end{array}$ & $\begin{array}{c}0.052 \\
(0.001)\end{array}$ & \\
\hline$\pi_{c}{ }^{a}$ & $\begin{array}{c}0.519 \\
(0.011)\end{array}$ & $\begin{array}{c}0.481 \\
(0.011)\end{array}$ & \\
\hline Constant & $\begin{array}{c}0.126^{* * *} \\
(0.033)\end{array}$ & $\begin{array}{c}0.730^{* * *} \\
(0.014)\end{array}$ & $\begin{array}{c}0.288^{* * *} \\
(0.028)\end{array}$ \\
\hline $\begin{array}{c}\text { Log-likelihood } \\
\text { Wald } \chi^{2}\end{array}$ & $\begin{array}{r}254 \\
5339\end{array}$ & $\begin{array}{l}.79 \\
1 * * *\end{array}$ & \\
\hline Adjusted $R^{2}$ & & & 0.475 \\
\hline VIF (average) & & & 4.77 \\
\hline $\mathrm{N}$ & & & 4310 \\
\hline
\end{tabular}

Note: Robust standard errors are in parentheses (Eicker-White correction) and the FMRM model converges in 14 iterations. Regressions also include activity sector dummies. The first component is the low quality of employment range and inversely for the second component.

${ }^{a} \pi_{c}$ is the probability that an observation is in component $c$. ${ }^{*} p<0.1,{ }^{* *} p<0.05,{ }^{* * *} p<0.01$.

Source: Authors, Departamento Administrativo Nacional de Estadistica (DANE): www.dane.gov.co

\subsection{Necessity networks as "bad quality job trap"}

Exploring the negative and significant correlation between using ties and the QoE index, two explanations have appeared relevant from the focus group interviews with vulnerable workers.

First, weak ties present an advantage by providing timely access to new and non-redundant informa- 
Table 4: FMRM and OLS for QoE index (independents), GIHS (2013)

\begin{tabular}{|c|c|c|c|}
\hline \multirow[b]{2}{*}{ Variable } & \multicolumn{2}{|c|}{ FMRM } & \multirow[t]{2}{*}{$\overline{\mathrm{OLS}}$} \\
\hline & Component 1 & Component 2 & \\
\hline Social Networks & $\begin{array}{c}\mathbf{- 0 . 0 4 5} \text { ** } \\
(0.020)\end{array}$ & $\begin{array}{r}\mathbf{- 0 . 0 0 5} \\
(0.005)\end{array}$ & $\begin{array}{c}-\mathbf{0 . 0 4 5}{ }^{* * *} \\
(0.011)\end{array}$ \\
\hline Age & $\begin{array}{l}-0.004 \\
(0.003)\end{array}$ & $\begin{array}{c}0.001 \\
(0.001)\end{array}$ & $\begin{array}{l}-0.003 \\
(0.002)\end{array}$ \\
\hline $\operatorname{Age}^{2}$ & $\begin{array}{c}0.000 \\
(0.000)\end{array}$ & $\begin{array}{l}-0.000 \\
(0.000)\end{array}$ & $\begin{array}{c}0.000 \\
(0.000)\end{array}$ \\
\hline Education & $\begin{array}{c}0.004^{* *} \\
(0.002)\end{array}$ & $\begin{array}{c}0.002^{* *} \\
(0.001)\end{array}$ & $\begin{array}{c}0.003^{* *} \\
(0.001)\end{array}$ \\
\hline Gender (women) & $\begin{array}{l}-0.006 \\
(0.015)\end{array}$ & $\begin{array}{l}-0.010 \\
(0.007)\end{array}$ & $\begin{array}{l}-0.002 \\
(0.012)\end{array}$ \\
\hline Strata 2 & $\begin{array}{c}0.052^{* *} \\
(0.020)\end{array}$ & $\begin{array}{c}0.035^{* * *} \\
(0.010)\end{array}$ & $\begin{array}{l}0.031^{*} \\
(0.018)\end{array}$ \\
\hline Strata 3 & $\begin{array}{c}0.074^{* * *} \\
(0.022)\end{array}$ & $\begin{array}{c}0.041^{* * *} \\
(0.010)\end{array}$ & $\begin{array}{c}0.056^{* * *} \\
(0.019)\end{array}$ \\
\hline Strata 4,5 et 6 & $\begin{array}{c}0.185^{* * *} \\
(0.030)\end{array}$ & $\begin{array}{c}0.049^{* * *} \\
(0.013)\end{array}$ & $\begin{array}{c}0.151^{* * *} \\
(0.023)\end{array}$ \\
\hline Married & $\begin{array}{c}0.021 \\
(0.014)\end{array}$ & $\begin{array}{c}0.007 \\
(0.006)\end{array}$ & $\begin{array}{l}0.019^{*} \\
(0.011)\end{array}$ \\
\hline$\lambda$ & $\begin{array}{c}0.525^{* * *} \\
(0.030)\end{array}$ & $\begin{array}{c}0.064^{* * *} \\
(0.013)\end{array}$ & $\begin{array}{c}0.516^{* * *} \\
(0.020)\end{array}$ \\
\hline$\sigma_{c}$ & $\begin{array}{c}0.153 \\
(0.004)\end{array}$ & $\begin{array}{c}0.050 \\
(0.002)\end{array}$ & \\
\hline$\pi_{c}{ }^{a}$ & $\begin{array}{c}0.575 \\
(0.020)\end{array}$ & $\begin{array}{c}0.425 \\
(0.020)\end{array}$ & \\
\hline Constant & $\begin{array}{c}0.265^{* *} \\
(0.077)\end{array}$ & $\begin{array}{c}0.696^{* * *} \\
(0.035)\end{array}$ & $\begin{array}{c}0.363^{* * *} \\
(0.061)\end{array}$ \\
\hline $\begin{array}{c}\text { Log-likelihood } \\
\text { Wald } \chi^{2}\end{array}$ & $\begin{array}{r}81 \\
4800\end{array}$ & $\begin{array}{l}89 \\
9 * * *\end{array}$ & \\
\hline Adjusted $R^{2}$ & & & 0.524 \\
\hline VIF (average) & & & 5.58 \\
\hline $\mathrm{N}$ & & & 1536 \\
\hline
\end{tabular}

Note: Robust standard errors are in parentheses (Eicker-White correction) and the FMRM model converges in 17 iterations. Regressions also include activity sector dummies. The first component is the low quality of employment range and inversely for the second component.

${ }^{a} \pi_{c}$ is the probability that an observation is in component $c$. ${ }^{*} p<0.1,{ }^{* *} p<0.05,{ }^{* * *} p<0.01$.

Source: Authors, Departamento Administrativo Nacional de Estadistica (DANE): www.dane.gov.co

tion, and by directly influencing employers (Yakubovitch 2005; Davern and Hachen 2006). In contrast, strong ties are associated with poor and redundant information, or with indirect influence on employers through well-connected intermediaries (Yakubovitch 2005). Finally, weak ties have been found to be more beneficial in accessing new information and to be an instrumental means in finding new jobs (Granovetter 1973; [1974] 1995). The three focus groups with vulnerable workers highlights that they are more likely to have and to use strong ties to obtain their current job. This qualitative observation could explain the 
negative correlation between relational embeddedness and the job quality for them (Tables 2, 3 and 4). In this way, Gloria, a 47-year-old woman living in stratum 2, highlighted her expectations of improving her quality of life. She explained that she directly contacted her close neighborhood friends to find a better job. After referring her to their employers, she finally obtained a job but it was not better than the previous one. Harold, a 26-year-old man living in stratum 3, found his last job through his father's contacts, but he had long working hours in a large company. They created a local union to negotiate better working conditions, but two months after the beginning of the negotiations, Harold was fired without unemployment benefits.

Second, we also could explain the negative correlation through the similarity shared between contacts in the social network of the vulnerable. Indeed, homophily isolates workers who present the same social characteristics as others with different attributes, which then limits the extent to which individuals in one group hear about openings and opportunities known to the other group (Reagans and Zuckerman 2001; Jackson et al. 2017). In other words, workers appealing to contacts who are in a same social situation (sharing the same characteristics) have a lower probability of achieving high labor market outcomes than workers appealing to diverse contacts who are in better social positions. In the focus groups of low job quality workers, we find that they have rarely contacted their parents or close friends in better positions than themselves because of trust issues. Patricia, a 30-year-old woman living in stratum 2, had been searching a job via specialized web pages and professional contacts who were in better social and occupational positions. However, these means proved unfruitful: her relatives' lack of information regarding her preferences and background as well as these websites being "unadapted" to her profile made the job search difficult. She found a job through close friends and family contacts in the same social position. Vanesa, a woman who lives in stratum 3, was in her fourth month of unemployment and was struggling to maintain her living standards. She had obtained her job through her mother's contacts with approximately the same social position as herself. Ultimately, she found a job with lower responsibilities and the same salary as the one before.

At the end, these qualitative results tend to confirm the H2b hypothesis presented in Section 3. Thanks to the focus groups interviews, we found that strong and homophilic ties are simultaneously a unique instrument of last resort and a negative resource for increasing the quality of employment for vulnerable workers, explaining the negative and significant correlation between using social networks and job quality. 


\subsection{Are opportunity networks really appropriate for accessing high quality jobs?}

We observe quantitatively that the use of networks is not significantly correlated with the QoE index for the protected workers (Tables 2, 3 and 4). We use the focus group interviews to better identify the relational mechanisms behind this result. Exploring it qualitatively, the non-negative correlation for these workers could be explained by their use of different types of networks (weak, professional and heterophilic ties) to obtain a job unlike vulnerable workers. However, this lack of significance could come from (i.) a social acceptance of worse working conditions in the short run (over-loyalty and over-subordination effects), (ii.) because using ties over formal means could send a bad signal to the labor market. Protected workers have all the necessary information and skills to obtain a job via other formal means but by choosing ties, they miss out on better opportunities.

Some studies show that the advantages of weak ties are clear for high-skilled workers (Granovetter [1974] 1995; Sharone 2014). The three focus groups of high job quality workers highlight that a majority has used weak ties to obtain their current job, and this can explain the non-negative correlation. Paula, a 26-year-old woman living in stratum 3, pointed out that she had found her previous job through a seconddegree contact. Indeed, she had received information from a school friend's uncle who worked at the firm. She was ultimately unsatisfied and decided to look for a new job. During this period, she received a lot of job offers sent by her school and professional contacts. Finally, she found her current job through the recommendation of an educated relative and in witch she has better responsibilities, a higher salary, and fewer working hours than in her last job. Camilo, a 28-year-old man living in stratum 4, pointed out that family members and close friends could not help him in the job search process. While a school friend had recommended him to his contacts, Camilo did not know them. He explained that for him this network process appeared "murky." There seems to be a signal effect: people did not know each other, but everyone in the network was trustworthy because they had the same educational background.

Moreover, individuals appealing to heterophilic contacts who are in a better social position have a higher probability of achieving better labor market outcomes (Reagans and Zuckerman 2001; Lin 2002). In the focus groups of these workers, we find that they have often contacted friends or relatives in a better position than themselves because their recommendations have greater impact than those of others. Odys, a 55 -year-old woman living in the stratum 4 , found clients through her managing directors' contacts. She has professional network with people in a better social position than herself that is effective because of 
their influence and provision of opportunities. Albeit she sometimes accepts lesser working conditions in order to maintain this professional network. Carlos, a 23-year-old man who lives in stratum 4, found his last job at the Central Bank of Colombia. In this occupational position, he had a strong professional network that sent him new job opportunities by mail. Using this means, Carlos found a job opportunity at the university. However, he did not apply there directly; a professional contact recommended him to a professor, who was the department director, allowing him to obtain the job. Yet in this new job, he accepted worse working conditions than his previous one. He explained that he needed to show his skills and his loyalty to the new occupational position, pending the transition towards better professional projects. The over-subordination effect in the short run appears clearly in some cases of this group.

These qualitative results tend to confirm the $H 1 b$ hypothesis presented in Section 3. Indeed, we show that weak, professional, and heterophilic ties constitute a better job channel, but they also generate an over-loyalty and over-subordination effect, conceivably explaining the non-positive correlation between using social relations and job quality.

\section{Discussions}

Thanks to a mixed approach, we have investigated the correlation between the use of social ties and the job quality in Bogota's labor market. Confirming Combarnous and Deguilhem (2016), our results demonstrate the relevance of treating the divide between vulnerable and protected workers rather than analyzing status typology (Bocquier et al. 2010). Quantitatively, the semi-parametric estimation (FMRM) shows a differential relation between social networks and the quality of employment for both groups. Indeed, we found a negative and significant correlation for vulnerable workers, and a non-significant correlation for protected ones. Qualitatively, we observe some different types of relational practices in terms of the strength of ties and social resources embedded in the networks of both worker' groups, explaining the quantitative effects. Confirming some of the sociological and economic literature, we show that strong and homophilic ties generates constraints for vulnerable workers. Conversely, weak, professional, and heterophilic ties constitute a productive job channel for protected people. However, these relations also engender over-loyalty and over-subordination effects, conceivably explaining why networks do not have a positive and significant correlation with the QoE index for these workers. Finally, these results provide lessons for improving the SPE for vulnerable workers in Bogota. In Colombia, this SPE was established in the last trimester of 2013, but the decree 2521 of 2013, which makes online registration a requirement 
for receiving unemployment benefits (cesantia), has greatly contributed to its expansion from more than 216,000 registrations in Bogota in 2014 to 476,000 in 2015 (SPE 2017). Despite this success, as well as the limitations posed by the need for online registration, the targeting of vulnerable workers is questionable. In 2017 , nearly $30 \%$ of unemployed workers in the capital had a university degree, and more than $20 \%$ declared themselves to be proficient in economics, humanities and social or educational sciences (SPE 2017). In light of our results, the SPE could redirect its action and specifically target vulnerable workers who would profit more by going through formal means than through their networks to increase their job quality.

The endogeneity, coming from a reverse causality, between the QoE index and the use of ties could be major issue (Mouw 2006). However, three remarks supports the results facing this problem. First, we analyze this relation only in terms of correlation insofar as the identification of a causal relationship from the networks remains very delicate (Fafchamps 2015; Shen and Bian 2018). Second, we capture the use of networks with an ex ante variable, while the measure of the QoE index is calculated from ex post variables (Appendix A). In other words, the relational variable reveals a retardation behavior before the current occupational status. Third, we can reasonably assume that this inverse causality supports the effects observed in the FMRM estimations. Indeed, some studies show that vulnerable workers receive little information about the possible opportunities because of their contacts' shared characteristics, such as the residential neighborhood, ethnicity, or conformism in individual practices through relationships (Fernandez and Fernandez-Mateo 2006; Smith 2016; Jackson et al. 2017; Parkinson et al. 2018).

Finally, given the limited number of variables in the GIHS, we had no opportunity to control for the cognitive and non-cognitive skills of the workers. Instead, we use a proxy with the number of years of education. Indeed, we could assume that the differential negative effects of relational factor on the QoE index is also influenced by workers' cognitive abilities and non-cognitive skills (Heckman et al. 2006). Furthermore, we think that geographical factors matter in analyzing the use of the social networks to get a job (Calvó-Armengol and Zenou 2005; Sato and Zenou 2015). However, we only refer to the socioeconomic stratum of each worker because do not have other spatial variables in the survey. Finally, this investigation of social networks allows us to distinguish between formal and relational means, but we have been unable to quantitatively explore the strength of ties, the structural dimensions of networks and the contacts' attributes, as well as to develop a social network analysis of ego-centered data (Nordman and Pasquier-Doumer 2015; Crossley et al. 2015; Berrou and Combarnous 2017). 


\section{References}

Antoninis, M. (2006). The wage effects from the use of personal contacts as hiring channels. Journal of Economic Behavior \& Organization, 59(1):133-146.

Beaman, L. (2016). Social networks and the labor market. In The Oxford Handbook of the Economics of Networks, pages 652-671. Oxford University Press.

Beaman, L., Keleher, N., and Magruder, J. R. (2018). Do job networks disadvantage women? evidence from a recruitment experiment in Malawi. Journal of Labor Economics, 36(1):121-157.

Beaman, L. and Magruder, J. R. (2012). Who gets the job referral? evidence from a social networks experiment. American Economic Review, 102(7):3574-3593.

Ben Salem, M. and Bensidoun, I. (2012). The heterogeneity of informal employment and segmentation in the Turkish labour market. Journal of the Asia Pacific Economy, 17(4):578-592.

Bentolila, S. V., Michelacci, C., and Suarez, J. (2010). Social contacts and occupational choice. Economica, $77(1): 20-45$.

Berrou, J. P. and Combarnous, F. (2011). Testing Lin's social capital theory in an informal African urban economy. Journal of Development Studies, 47(8):1216-1240.

Berrou, J. P. and Combarnous, F. (2012). The personal networks of entrepreneurs in an informal African urban economy: Does the 'strength of ties' matter? Review of Social Economy, 70(1):1-30.

Berrou, J. P. and Combarnous, F. (2017). Beyond solidarity and accumulation networks in urban informal african economies. European Journal of Development Research, 0(0):1-24.

Bocquier, P., Nordman, C. J., and Vescovo, A. (2010). Employment vulnerability and earnings in urban West Africa. World Development, 38(9):1297-1314.

Bott, E. (2002). Family and Social Network: Roles, Norms and External Relationships in Ordinary Urban Families. Routledge, New York, 3rd edition.

Brady, G. (2015). Network social capital and labour market outcomes: Evidence for Ireland. The Economic and Social Review, 46(2):163-195.

Bramoullé, Y. and Saint-Paul, G. (2010). Social networks and labor market transitions. Labour Economics, 17(1):188-195.

Burchell, B., Sehnbruch, K., Piasna, A., and Agloni, N. (2014). The quality of employment and decent work: Definitions, methodologies, and ongoing debates. Cambridge Journal of Economics, 38(2):459477 .

Burt, R. (1995). Structural Holes: The Social Structure of Competition. Harvard University Press, New York.

Callon, M. (1998). Laws of the markets. Wiley-Blackwell, Oxford, 1st edition.

Calvó-Armengol, A. and Jackson, M. O. (2004). The effects of social networks on employment and inequality. American Economic Review, 93(3):426-454.

Calvó-Armengol, A. and Jackson, M. O. (2007). Networks in labor markets: Wage and employment dynamics and inequality. Journal of Economic Theory, 132(1):27-46.

Calvó-Armengol, A. and Zenou, Y. (2005). Job matching, social network and word-of-mouth communication. Journal of Urban Economics, 57(1):500-522.

Chua, V. (2011). Social networks and labour market outcomes in a meritocracy. Social Networks, 33(1):111. 
Combarnous, F. and Deguilhem, T. (2016). Urban labor market revisited: Why quality of employment matters in Bogota. Working Paper SSRN, ( $\left.{ }^{\circ} 2784763\right)$.

Crona, B., Gelcich, S., and Bodin, O. (2017). The importance of interplay between leadership and social capital in shaping outcomes of rights-based fisheries governance. World Development, 91(1):70-83.

Crossley, N., Bellotti, E., Edwards, G., Everett, M. G., and Tranmer, M. (2015). Social Network Analysis for EGO-Nets. Sage Publications, London.

Datcher Loury, L. (2006). Some contacts are more equal than others: Informal networks, job tenure, and wages. Journal of Labor Economics, 24(2):299-318.

Davern, M. and Hachen, D. S. (2006). The role of information and influence in social networks. American Journal of Economics \&3 Sociology, 65(2):269-293.

Deb, P., Gallo, W. T., Ayyagari, P., Fletcher, J. M., and Sindelar, J. L. (2011). The effect of job loss on overweight and drinking. Journal of Health Economics, 30(2):317-327.

Departamento Administrativo Nacional de Estadistica (2014). Principales indicadores del mercado laboral - Departamentos 2013. Technical report, DANE, Bogota.

Di Falco, S., Feri, F., Pin, P., and Vollenweider, X. (2018). Ties that bind: Network redistributive pressure and economic decisions in village economies. Journal of Development Economics, 131(1):123-131.

Diaz, A. M. (2012). Informal referrals, employment, and wages: Seeking causal relationships. Labour, $26(1): 1-30$.

Dureau, F., Lulle, T., Souchaud, S., and Contreras, Y. (2015). Movilidad y cambio urbano: Bogota, Santiago y São Paulo. Universidad El Externado de Colombia, Bogota.

Ekinci, E. (2016). Employee referrals as a screening device. RAND Journal of Economics, 47(3):688-708.

Elliott, J. R. and Sims, M. (2001). Social networks and labour market outcomes in a meritocracy. Social Problems, 48(3):341-361.

Fafchamps, M. (2006). Development and social capital. Journal of Development Studies, 42(7):1180-1198.

Fafchamps, M. (2015). Causal effects in social networks. Revue Economique, 66(4):657-686.

Farné, S. and Vergara, C. A. (2015). Economic growth, labour flexibilization and employment quality in Colombia, 2002-11. International Labour Review, 154(2):253-269.

Fernandez, R. M. and Fernandez-Mateo, I. (2006). Networks, race, and hiring. American Sociological Review, 71(1):42-71.

Fields, G. S. (2011). Labor market analysis for developing countries. Labour Economics, 18(1):S16-S22.

Floro, M. S. and Messier, J. (2011). Is there a link between quality of employment and indebtedness? The case of urban low-income households in Ecuador. Cambridge Journal of Economics, 35(3):499-526.

Granovetter, M. S. (1973). The strength of weak ties. American Journal of Sociology, 78(6):1360-1380.

Granovetter, M. S. (1982). The strength of weak ties: A network theory revisited. In Social Structure and Network Analysis, pages 501-518. Academic Press.

Granovetter, M. S. (1985). Economic action and social structure: The problem of embeddedness. American Journal of Sociology, 91(3):481-510.

Granovetter, M. S. (1995). Getting a Job. A Study of Contacts and Carreers. University of Chicago Press, 2nd edition. 
Granovetter, M. S. (2017). Society and Economy: Framework and Principles. Harvard University Press, 1st edition.

Greenacre, M. J. (1993). Correspondence Analysis in Practice. Academic Press, London.

Grossetti, M. (2005). Where do social relations come from? a study of personal networks in the Toulouse area of France. Social Networks, 27(1):289-300.

Günther, I. and Launov, A. (2012). Informal employment in developing countries: opportunity or last resort? Journal of Development Economics, 97(1):88-98.

Hamermesh, D. S. and Stancanelli, E. (2015). Long workweeks and strange hours. Industrial \& Labour Relations Review, 68(5):1007-1018.

Heckman, J. J. (1979). Sample selection bias as a specification error. Econometrica, 47(1):153-161.

Heckman, J. J., Stixrud, J., and Urzua, S. (2006). The effects of cognitive and noncognitive abilities on labor market outcomes and social behavior. Journal of Labor Economics, 24(3):411-482.

Hensvik, L. and Skans, O. N. (2016). Social networks, employee selection, and labor market outcomes. Journal of Labor Economics, 34(4):825-867.

Hudson, K. (2007). The new labor market segmentation: Labor market dualism in the new economy. Social Science Research, 36(1):286-312.

Jackson, M. O. Rogers, B. and Zenou, Y. (2017). The economic consequences of social network structure. Journal of Economic Literature, 55(1):49-95.

Jackson, M. O. (2014). Networks in the understanding of economic behaviors. Journal of Economic Perspectives, 28(4):3-22.

Kalleberg, A. L., Reskin, B. F., and Hudson, K. (2000). Bad jobs in America: standard and nonstandard employment relations and job quality in the United States. American Sociological Reviw, 65(1):256278.

Kramarz, F. and Skans, O. N. (2014). When strong ties are strong: Networks and youth labour market entry. Review of Economic Studies, 81(1):1164-1200.

Kugler, A. D. (2003). Employee referrals and efficiency wages. Labour Economics, 10(5):531-556.

Lin, N. (2002). Social Capital: A Theory of Social Structure and Action. Cambridge University Press, New York.

Madriz, E. I. (1998). Using focus groups with lower socioeconomic status Latina women. Qualitative Inquiry, 4(1):114-128.

Magruder, J. R. (2010). Intergenerational networks, unemployment, and persistent inequality in South Africa. American Economic Journal: Applied Economics, 2(1):62-85.

Marques, E. (2012). Social networks, segregation and poverty in São Paulo. International Journal of Urban and Regional Research, 36(5):958-979.

Marsden, P. V. and Gorman, E. H. (2001). Social networks, job changes, and recruitment. In Sourcebook of Labor Markets, pages 467-502. Springer.

Matsuda, N. and Nomura, S. (2017). Fast, easy and cheap job matching: Social networks in Bangladesh. Policy Research Working Paper, World Bank, (N 8107$)$.

McLachlan, G. and Peel, D. (2000). Mixtures of Factor Analyzers. In Finite Mixture Models, pages 238-256. John Wiley \& Sons, Inc. 
McMillan, M., Rodrik, D., and Verduzco-Gallo, I. (2014). Globalization, structural change, and productivity growth, with an update on Africa. World Development, 63(1):11-32.

Mouw, T. (2006). Estimating the causal effect of social capital: A review of recent research. Annual Review of Sociology, 32(1):79-102.

Nguyen, C. H. Nordman, C. J. (2018). Household entrepreneurship and social networks: Panel data evidence from Vietnam. Journal of Development Studies, 54(4):594-618.

Nicodemo, C. and García, A. G. (2015). Job search channels, neighborhood effects, and wages inequality in developing countries: The Colombian case. Developing Economies, 53(2):75-99.

Nordman, C. J. and Pasquier-Doumer, L. (2015). Transitions in a West African labour market: The role of family networks. Journal of Behavioral \&3 Experimental Economics, 54(1):74-95.

OECD (2008). Handbook on constructing composite indicators. Technical report, OECD Publishing, Paris.

OECD (2016). Employment outlook 2016. Technical report, OECD Publishing, Paris.

Osterman, P. (2013). Introduction to the special issue on job quality: What does it mean and how might we think about it? Industrial \& Labor Relations Review, 66(4):739-752.

Parkinson, C., Kleinbaum, A. M., and Wheatley, T. (2018). Similar neural responses predict friendship. Nature Communications, 9(332):1-14.

Pellizzari, M. (2010). Do friends and relatives really help in getting a good job? Industrial \& Labor Relations Review, 63(3):494-510.

Portes, A. (2010). Economic Sociology: A Systematic Inquiry. Princeton University Press, New York.

Rauch, J. E. and Cassella, A. (2001). Networks and Markets. Russel Sage Foundation, New York.

Reagans, R. and Zuckerman, E. W. (2001). Networks, diversity, and productivity: The social capital of corporate R\&D teams. Organization Science, 12(4):502-517.

Sato, Y. and Zenou, Y. (2015). How urbanization affect employment and social interactions. European Economic Review, 75(1):131-155.

Servicio Distrital de Planeación (2013). Segregación socioeconomica en el espacio urbano de Bogota D.C. Secretaria Distrital de Planeacion and Universidad Nacional de Colombia, Bogota.

Servicio Público de Empleo (2017). Informe estadístico de indicadores de gestión del Servicio Público de Empleo. Technical report, Observatorio de Empleo, Bogota.

Sharone, O. (2014). Social capital activation and job searching: Embedding the use of weak ties in the American institutional context. Work and Occupations, 41(4):409-439.

Shen, J. and Bian, Y. (2018). The causal effect of social capital on income: A new analytic strategy. Social Networks, 54(1):82-90.

Smelser, N. and Swedberg, R. (2005). The Handbook of Economic Sociology. Princeton University Press, 2nd edition.

Smith, S. S. (2000). Mobilizing social resources: Race, ethnic, and gender differences in social capital and persisting wage inequalities. The Sociological Quarterly, 41(4):509-537.

Smith, S. S. (2016). Job-finding among the poor: Do social ties matter? In Oxford Handbook of Poverty and Society, pages 438-460. Oxford University Press. 
Tholen, G. Brown, P., Power, S., and Allouch, A. (2013). The role of networks and connections in educational elites' labour market entrance. Research in Social Stratification and Mobility, 34(1):142154.

Tokman, V. E. (2007). The informal economy, insecurity and social cohesion in Latin America. International Labour Review, 146(1-2):81-107.

Topa, G. (2011). Labor markets and referrals. In Handbook of Social Economics, pages 1193-1221. Elsevier.

World Bank (2013). Jobs. Technical report, World Bank Publishing, Washington DC.

Yakubovich, V. (2005). Weak ties, information, and influence: How workers find jobs in a local Russian labor market. American Sociological Review, 70(3):408-421.

Yogo, U. T. (2011). Social network and wage: Evidence from Cameroon. Labour, 25(4):528-543.

Zhang, Y., Zhou, X., and Lei, W. (2017). Social capital and its contingent value in poverty reduction: Evidence from Western China. World Development, 93(1):350-361. 


\section{APPENDIX}

\section{Appendix A}

Table A.1: Indicators of the QoE index, GIHS (2013)

\begin{tabular}{|c|l|}
\hline Indicators & Characterizations \\
\hline Income & $\begin{array}{l}1 \text { if individual earns less than the minimum wage (MW); } 2 \text { if individual earns } \\
\text { less than } 2 \mathrm{MW} ; 3 \text { if individual earns less than } 4 \mathrm{MW} ; 4 \text { if individual earns } \\
\text { more than } 4 \mathrm{MW}\end{array}$ \\
\hline Stability & 1 if more than 1 year; 2 if not \\
\hline Contract completeness & See the note under the table \\
\hline Other activity & 1 if yes; 2 if not \\
\hline Workplace & 1 if individual works in hard local; 2 if household work; 3 if other \\
\hline Transport & 1 if individual has transport benefits; 2 if not \\
\hline Time & $\begin{array}{l}1 \text { if individual works less than } 24 \text { hours per week; } 2 \text { if he works between } 24 \\
\text { and } 48 \text { hours per week (legal employment); } 3 \text { if he works more than } 48 \text { hours } \\
\text { per week }\end{array}$ \\
\hline Social security & $\begin{array}{l}1 \text { if individual contributes to social security; } 2 \text { if he has special social security } \\
\text { (Army, Ecopetrol, Public University); } 3 \text { if he has subsidized social security; } 4 \\
\text { if not }\end{array}$ \\
\hline Occupation risk & 1 if individual has an occupation protection; 2 if not \\
\hline Pension & 1 if individual has a pension; 2 if not \\
\hline Family fund & 1 if individual has a family protection system; 2 if not \\
\hline Union & 1 if he is in a union; 2 if not \\
\hline Subjectivity & See the note under the table \\
\hline
\end{tabular}

Note: The Contract completeness indicator is a scoring variable constructed from seven variables of contract composition. Category 0 illustrates the situation of workers without any forms of contract; category 1 identifies the primary elements of formal contract. Category 2 marks the passage to a written contract, but contents of which remain rather weak. Category 3 marks the appearance of social contents in contracts, 4 and 5 are complete contracts. We do not presume the importance of every category, of this fact weighting method is not necessary. The Subjectivity indicator constitutes an objective indicator of the subjective representations. Like the QoE index, this variable is a synthesis constructed across MCA from eight variables expressing the necessity of change and the satisfaction of workers. The first factorial axis explaining more than $88 \%$ of the corrected eigenvalues (Greenacre 1993), it can be defined as the factor of workers' satisfaction. After analysis of distribution, we have discretized this quantitative variable in three groups: 1 is a good satisfaction level and a will to stay in current job, 2 is an intermediate satisfaction level and 3 a dissatisfaction level. 


\section{Appendix B}

Table B.1: Descriptive statistics, GIHS (2013)

\begin{tabular}{|c|c|c|c|c|c|c|c|}
\hline & \multirow{2}{*}{ Total sample } & \multicolumn{2}{|c|}{ Social Net. } & \multirow{2}{*}{$\begin{array}{c}\text { Social Net. } \\
\text { Yes }\end{array}$} & \multirow{2}{*}{$\begin{array}{c}\text { (Employees) } \\
\text { No }\end{array}$} & \multirow{2}{*}{$\begin{array}{c}\text { Social Net. } \\
\text { Yes }\end{array}$} & \multirow{2}{*}{$\begin{array}{c}\text { (Independents) } \\
\text { No }\end{array}$} \\
\hline & & Yes & No & & & & \\
\hline QoE index & 0.6214 & 0.5592 & 0.7365 & 0.5743 & 0.7399 & 0.5207 & 0.7252 \\
\hline SD. & $(0.258)$ & $(0.273)$ & $(0.178)$ & $(0.269)$ & $(0.180)$ & $(0.277)$ & $(0.171)$ \\
\hline Income (per hour) & 5926.31 & 5243.93 & 7187.99 & 5225.69 & 7421.19 & 5290.48 & 6398.69 \\
\hline SD. & $(7918.46)$ & $(6943.69)$ & $(9331.15)$ & $(6561.40)$ & $(9843.68)$ & $(7838.49)$ & $(7289.36)$ \\
\hline Age & 44.78 & 44.75 & 44.84 & 43.07 & 42.89 & 49.04 & 51.43 \\
\hline SD. & $(14.55)$ & $(14.50)$ & $(14.64)$ & $(14.80)$ & $(14.47)$ & $(12.73)$ & $(13.23)$ \\
\hline Education (years) & 10.09 & 9.60 & 10.98 & 9.77 & 11.36 & 9.17 & 9.72 \\
\hline SD. & $(4.82)$ & $(4.73)$ & $(4.85)$ & $(4.62)$ & $(4.77)$ & $(5.00)$ & $(4.94)$ \\
\hline Number of people & 3.45 & 3.50 & 3.37 & 3.28 & 3.19 & 4.05 & 3.96 \\
\hline SD. & $(1.56)$ & $(1.57)$ & $(1.52)$ & $(1.55)$ & $(1.51)$ & $(1.50)$ & $(1.41)$ \\
\hline Gender, women (\%) & 36.08 & 35.66 & 36.84 & 38.63 & 38.95 & 28.10 & 29.70 \\
\hline Married (\%) & 28.02 & 27.28 & $\begin{array}{l}29.39 \\
29.39\end{array}$ & 23.51 & 26.70 & 36.89 & 38.46 \\
\hline Strata $1(\%)$ & 11.60 & 11.89 & 11.06 & 12.40 & 11.17 & 10.58 & $\begin{array}{l}30.40 \\
10.68\end{array}$ \\
\hline Strata $2(\%)$ & 44.44 & 45.97 & 41.62 & 47.21 & 41.35 & 42.79 & 42.52 \\
\hline Strata $3(\%)$ & 33.73 & 32.50 & 36.01 & 31.51 & 35.80 & 35.02 & 36.75 \\
\hline Strata $4^{a}(\%)$ & 10.23 & 9.65 & 11.31 & 8.88 & 11.68 & 11.61 & 10.04 \\
\hline Internet at home (\%) & 54.02 & 50.42 & 60.67 & 47.14 & 58.02 & 58.80 & 69.66 \\
\hline At least one car $(\%)$ & 20.87 & 19.74 & 22.95 & 15.85 & 21.91 & 29.98 & 26.50 \\
\hline Owner $(\%)$ & 30.36 & 29.44 & 32.07 & 26.96 & 28.41 & 35.77 & 44.44 \\
\hline Self-employed (\%) & 5.80 & 8.59 & 0.63 & 9.00 & 0.69 & 7.58 & 0.43 \\
\hline $2-5$ employees $(\%)$ & 18.66 & 25.88 & 5.31 & 23.26 & 5.74 & 32.58 & 3.85 \\
\hline $6-10$ employees (\%) & 8.40 & 10.25 & 4.97 & 10.31 & 5.11 & 10.11 & 4.45 \\
\hline $11-50$ employees $(\%)$ & 15.45 & 17.32 & 11.99 & 18.20 & 10.86 & 15.07 & 15.81 \\
\hline $51-100$ employees $(\%)$ & 5.20 & 4.69 & 6.14 & 5.00 & 6.12 & 3.93 & 6.20 \\
\hline More than 100 employees (\%) & 46.49 & 33.26 & 70.96 & 34.26 & 71.46 & 30.71 & 69.23 \\
\hline Manufacturing (\%) & 16.62 & 16.70 & 16.47 & 16.87 & 16.04 & 16.29 & 17.94 \\
\hline Commercial services (\%) & 17.19 & 18.90 & 14.04 & 18.09 & 13.19 & 20.97 & 16.80 \\
\hline Transport $(\%)$ & 8.18 & 8.17 & 8.19 & 8.80 & 7.51 & 6.55 & 10.47 \\
\hline Finance, Real Estate (\%) & 18.73 & 16.39 & 23.05 & 15.85 & 22.98 & 17.79 & 23.29 \\
\hline Domestic work (\%) & 9.80 & 13.31 & 3.31 & 13.50 & 3.35 & 12.83 & 3.21 \\
\hline Hotels, Restaurants (\%) & 7.63 & 8.80 & 5.46 & 9.06 & 5.74 & 8.15 & 4.49 \\
\hline Public Administration (\%) & 4.53 & 2.21 & 8.82 & 2.31 & 9.60 & 1.97 & 6.20 \\
\hline Education private/public (\%) & 6.10 & 3.82 & 10.33 & 3.78 & 10.54 & 3.93 & 9.62 \\
\hline Social and medical (\%) & 5.23 & 4.35 & 6.87 & 4.37 & 7.01 & 4.31 & 6.41 \\
\hline $\mathrm{N}$ & 5846 & 3794 & 2052 & 2726 & 1584 & 1068 & 468 \\
\hline
\end{tabular}

Source: Authors, , Departamento Administrativo Nacional de Estadistica (DANE): WWW.dane.gov.co 


\section{Appendix C}

Table C.1: Marginal effects on the probability of using networks, GIHS (2013)

\begin{tabular}{|c|c|c|c|c|c|c|}
\hline Variable & \multicolumn{2}{|c|}{ Probit(1) } & \multicolumn{2}{|c|}{ Probit $(2)$} & \multicolumn{2}{|c|}{ Probit $(3)$} \\
\hline Education $(I C F E S)$ & $-0.039^{* *}$ & $(0.017)$ & $-0.038^{*}$ & $(0.020)$ & -0.050 & $(0.032)$ \\
\hline Education (Techno.) & $-0.101^{* * *}$ & $(0.023)$ & $-0.117^{* * *}$ & $(0.027)$ & -0.059 & $(0.044)$ \\
\hline Education (Univers.) & $-0.085^{* * *}$ & $(0.001)$ & $-0.121^{* * *}$ & $(0.029)$ & 0.015 & $(0.039)$ \\
\hline Age & -0.001 & $(0.001)$ & -0.001 & $(0.001)$ & -0.001 & $(0.001)$ \\
\hline Gender (women) & -0.007 & $(0.014)$ & -0.008 & $(0.016)$ & 0.016 & $(0.026)$ \\
\hline Internet & -0.011 & $(0.015)$ & 0.003 & $(0.017)$ & $-0.054^{* *}$ & $(0.026)$ \\
\hline Nb. people & 0.005 & $(0.004)$ & 0.002 & $(0.005)$ & 0.007 & $(0.008)$ \\
\hline Car & 0.028 & $(0.018)$ & -0.002 & $(0.023)$ & $0.074^{* *}$ & $(0.028)$ \\
\hline Owner & -0.001 & $(0.017)$ & 0.010 & $(0.020)$ & -0.028 & $(0.028)$ \\
\hline 2-5 employees & $-0.190 * * *$ & $(0.053)$ & $-0.233^{* * *}$ & $(0.059)$ & -0.101 & $(0.110)$ \\
\hline 6-10 employees & $-0.371^{* * *}$ & $(0.052)$ & $-0.374^{* * *}$ & $(0.056)$ & $-0.359^{* * *}$ & $(0.125)$ \\
\hline $11-50$ employees & $-0.435^{* * *}$ & $(0.046)$ & $-0.399 * * *$ & $(0.053)$ & $-0.524^{* * *}$ & $(0.102)$ \\
\hline 51-100 employees & $-0.548^{* * *}$ & $(0.037)$ & $-0.530 * * *$ & $(0.041)$ & $-0.613^{* * *}$ & $(0.084)$ \\
\hline More than 100 & $-0.601^{* * *}$ & $(0.033)$ & $-0.599 * * *$ & $(0.037)$ & $-0.596^{* * *}$ & $(0.078)$ \\
\hline Log-likelihood & \multicolumn{2}{|c|}{-3255.98} & \multicolumn{2}{|c|}{-2455.27} & \multicolumn{2}{|c|}{-775.71} \\
\hline LR $\chi^{2}$ & \multicolumn{2}{|c|}{$1065.26^{* * *}$} & \multicolumn{2}{|c|}{$758.15^{* * *}$} & \multicolumn{2}{|c|}{$337.19^{* * *}$} \\
\hline Adjusted Pseudo $R^{2}$ (McFadden) & \multicolumn{2}{|c|}{0.137} & \multicolumn{2}{|c|}{0.128} & \multicolumn{2}{|c|}{0.163} \\
\hline$R^{2}$ (Effron) & \multicolumn{2}{|c|}{0.165} & \multicolumn{2}{|c|}{0.161} & \multicolumn{2}{|c|}{0.190} \\
\hline Predict. P. & \multicolumn{2}{|c|}{0.683} & \multicolumn{2}{|c|}{0.661} & \multicolumn{2}{|c|}{0.751} \\
\hline $\mathrm{N}$ & \multicolumn{2}{|c|}{5846} & \multicolumn{2}{|c|}{4310} & \multicolumn{2}{|c|}{1536} \\
\hline
\end{tabular}

Note: The first model treats all sample, the second treats only the employees and the third only the independents. Standard errors are in parentheses. ${ }^{*} p<0.1,{ }^{* *} p<0.05,{ }^{* * *} p<0.01$.

Source: Authors, Departamento Administrativo Nacional de Estadística (DANE): www.dane.gov.co 


\section{Appendix D}

Table D.1: Quantile regression (Total sample), GISH (2013)

\begin{tabular}{|c|c|c|c|c|c|c|}
\hline \multirow[b]{2}{*}{ Variable } & \multicolumn{6}{|c|}{ Quantile regression } \\
\hline & q10 & q20 & q30 & $\mathrm{q} 70$ & q80 & q90 \\
\hline Social Networks & $\begin{array}{c}-0.043^{* * *} \\
(0.011)\end{array}$ & $\begin{array}{c}-0.032 * * * \\
(0.007)\end{array}$ & $\begin{array}{c}-0.025 * * * \\
(0.005)\end{array}$ & $\begin{array}{c}-0.011^{* * *} \\
(0.004)\end{array}$ & $\begin{array}{l}-0.004 \\
(0.003)\end{array}$ & $\begin{array}{l}-0.003 \\
(0.003)\end{array}$ \\
\hline \multicolumn{7}{|l|}{ Controls : } \\
\hline Individual characteristics ${ }^{a}$ & $\checkmark$ & $\checkmark$ & $\checkmark$ & $\checkmark$ & $\checkmark$ & $\checkmark$ \\
\hline Household characteristics ${ }^{a}$ & $\checkmark$ & $\checkmark$ & $\checkmark$ & $\checkmark$ & $\checkmark$ & $\checkmark$ \\
\hline Employment characteristics ${ }^{a}$ & $\checkmark$ & $\checkmark$ & $\checkmark$ & $\checkmark$ & $\checkmark$ & $\checkmark$ \\
\hline$\lambda$ & $\checkmark$ & $\checkmark$ & $\checkmark$ & $\checkmark$ & $\checkmark$ & $\checkmark$ \\
\hline Pseudo $R^{2}$ & 0.327 & 0.425 & 0.456 & 0.146 & 0.107 & 0.070 \\
\hline $\mathrm{N}$ & 5846 & 5846 & 5846 & 5846 & 5846 & 5846 \\
\hline
\end{tabular}

Note: ${ }^{a}$ The same variables as the FMRM regressions are used.

Bootstrapped standard errors are in parenthesis (500 replications).

${ }^{*} p<0.1, * * p<0.05, * * * p<0.01$.

Source: Authors, Departamento Administrativo Nacional de Estadística (DANE): Www. dane.gov.co

Table D.2: Quantile regression (Employees), GISH (2013)

\begin{tabular}{|c|c|c|c|c|c|c|}
\hline \multirow[b]{2}{*}{ Variable } & \multicolumn{6}{|c|}{ Quantile regression } \\
\hline & q10 & $\mathrm{q} 20$ & q30 & q70 & q80 & q90 \\
\hline Social Networks & $\begin{array}{c}-0.051^{* * *} \\
(0.014)\end{array}$ & $\begin{array}{c}-0.030 * * * \\
(0.007)\end{array}$ & $\begin{array}{c}-0.022^{* * *} * \\
(0.006)\end{array}$ & $\begin{array}{l}-0.007 \\
(0.004)\end{array}$ & $\begin{array}{c}-0.003 \\
(0.003)\end{array}$ & $\begin{array}{l}-0.001 \\
(0.003)\end{array}$ \\
\hline \multicolumn{7}{|l|}{ Controls : } \\
\hline Individual characteristics ${ }^{a}$ & $\checkmark$ & $\checkmark$ & $\checkmark$ & $\checkmark$ & $\checkmark$ & $\checkmark$ \\
\hline Household characteristics ${ }^{a}$ & $\checkmark$ & $\checkmark$ & $\checkmark$ & $\checkmark$ & $\checkmark$ & $\checkmark$ \\
\hline Employment characteristics ${ }^{a}$ & $\checkmark$ & $\checkmark$ & $\checkmark$ & $\checkmark$ & $\checkmark$ & $\checkmark$ \\
\hline$\lambda$ & $\checkmark$ & $\checkmark$ & $\checkmark$ & $\checkmark$ & $\checkmark$ & $\checkmark$ \\
\hline Pseudo $R^{2}$ & 0.338 & 0.425 & 0.439 & 0.128 & 0.094 & 0.062 \\
\hline $\mathrm{N}$ & 4310 & 4310 & 4310 & 4310 & 4310 & 4310 \\
\hline
\end{tabular}

Note: ${ }^{a}$ The same variables as the FMRM regressions are used.

Bootstrapped standard errors are in parenthesis (500 replications).

${ }^{*} p<0.1,{ }^{*} p<0.05, * * * p<0.01$.

Source: Authors, Departamento Administrativo Nacional de Estadistica (DANE): WwW. dane.gov.co

Table D.3: Quantile regression (Independents), GISH (2013)

\begin{tabular}{|c|c|c|c|c|c|c|}
\hline \multirow[b]{2}{*}{ Variable } & \multicolumn{6}{|c|}{ Quantile regression } \\
\hline & $\mathrm{q} 10$ & $\mathrm{q} 20$ & q30 & q70 & q80 & q90 \\
\hline Social Networks & $\begin{array}{c}-0.043^{* * *} \\
(0.030)\end{array}$ & $\begin{array}{c}-0.054^{* * *} \\
(0.019)\end{array}$ & $\begin{array}{c}-0.034^{* *} \\
(0.014)\end{array}$ & $\begin{array}{c}-0.027^{* *} \\
(0.011)\end{array}$ & $\begin{array}{c}-0.018^{*} \\
(0.009)\end{array}$ & $\begin{array}{c}-0.014^{* *} \\
(0.007)\end{array}$ \\
\hline \multicolumn{7}{|l|}{ Controls : } \\
\hline Individual characteristics $^{a}$ & $\checkmark$ & $\checkmark$ & $\checkmark$ & $\checkmark$ & $\checkmark$ & $\checkmark$ \\
\hline Household characteristics ${ }^{a}$ & $\checkmark$ & $\checkmark$ & $\checkmark$ & $\checkmark$ & $\checkmark$ & $\checkmark$ \\
\hline Employment characteristics ${ }^{a}$ & $\checkmark$ & $\checkmark$ & $\checkmark$ & $\checkmark$ & $\checkmark$ & $\checkmark$ \\
\hline$\lambda$ & $\checkmark$ & $\checkmark$ & $\checkmark$ & $\checkmark$ & $\checkmark$ & $\checkmark$ \\
\hline Pseudo $R^{2}$ & 0.274 & 0.387 & 0.446 & 0.211 & 0.145 & 0.104 \\
\hline $\mathrm{N}$ & 1536 & 1536 & 1536 & 1536 & 1536 & 1536 \\
\hline
\end{tabular}

Note: ${ }^{a}$ The same variables as the FMRM regressions are used.

Bootstrapped standard errors are in parenthesis (500 replications).

${ }^{*} p<0.1, * * p<0.05, * * * p<0.01$.

Source: Authors, Departamento Administrativo Nacional de Estadistica (DANE): Www.

dane.gov.co 